\title{
Kazakh sports culture: theory and practice
}

\section{${ }^{1}$ Sapanov S.Zh., ${ }^{2}$ Zhanabayev K., ${ }^{3}$ Kairgaliyeva G, ${ }^{4}$ YermagambetovaA. U., ${ }^{5}$ Murtaza A.Sh., ${ }^{6}$ Akserikov G.E., ${ }^{7}$ ZhumabayevaK.ZH.}

${ }^{1}$ Doctor of historic science,NAO Atyrau University named after Kh. Dosmukhamedova D. I., Director of the ${ }^{2}$ Research Institute "History, Archeology and Ethnology of the Caspian region named after Kh. B. Tabyldiev" Atyrau, Kazakhstan,

${ }^{3}$ candidate of philological sciences, KazNU named after Al-Farabi, Department of Publishing, Editorial and Design Art, Almaty, Kazakhstan,

${ }^{4}$ NAO Atyrau University named after Kh. Dosmaganbetov, candidate of historic science Atyrau, Kazakhstan

${ }^{5}$ Senior lecturer Department of Pre-university training, KazNU named after Al-Farabi, Almaty, Kazakhstan,

${ }^{6}$ NAO Atyrau University named after Kh. Dosmaganbetov, Department of General Physical Culture, Atyrau, Kazakhstan,

${ }^{7}$ Master of pedagogy, KazNU named after Al-Farabi, Department of pedagogy and educational management, Almaty, Kazakhstan,

11cefosh1@gmail.com, ${ }^{2}$ ovlur1963@mail.ru, ${ }^{3}$ gkairgaliyeva@asu.edu.kz, ${ }^{4}$ ania_erm@mail.ru, ${ }^{5}$ cefosh1@mail.ru, ${ }^{6}$ cefosh1@mail.ru, ${ }^{7}$ zhumabaeva1995@list.ru

Article History: Received:11 november 2020; Accepted: 27 December 2020; Published online: 23 January 2021

Abstract: T Important theoretical aspects are considered in this article: the origin and essence of the Kazakh controversial culture. Sport competitive culture is the only part of the general agonistics, which includes various other kinds of competitions: poetic, musical etc., and Kazakh controversial culture is a part of the universal human culture.

The questions of sports culture and philosophy, especially its agonistic context, seem to be the most complex, interesting and relevant. However, deep theoretical development is required to understand the essence of agon in the world and national sports culture, as one of the most socially demanded and the most developed variety of culture.

Agonistics as a cultural phenomenon attracts the attention of the world scientific community: culturologists, philosophers, art historians, economists, teachers, etc. We have taken the Kazakh example, the method of comparing the world's agon with the Kazakh tradition: its ancient sources, its national-specific characteristics, its organic connection with the initial bases: martial arts, rituals and sports games of ancient Turkic peoples to identify the essence, origin, forms of agon. Such a national-theoretical approach sheds light not only on the specifics, but also on the general laws of the development of a sportcompetitive culture, on the common origins and the universal essence of adversarial (agon) in its various manifestations and not only sports. The article explores theoretical approaches, interpretations of foreign, Kazakh philosophers and culturologists. This scientific theoretical and methodological base is of fundamental importance for studying the essence and genesis of world sports and sports phenomena.

Keywords: Kazakh agon, agonistic genres and forms, military rites and rituals, genesis, dialectics, interpretation, concept, initial foundations, essence, specifics, tradition.

\section{Introduction}

This article is part of a large scientific complex cultural research devoted to the origin of a sports-competitive culture (genesis) and its essence.Kazakh agonistic culture was able to preserve the ancient traditions and national-specific features up to the 21 st century because in the center of culture there is a person that is usually associated with the fact that they compare it with the Kazakh national temperament: with its ancient sources, nationally meaningful semantics, with initial grounds: martial arts, rituals and military sports games of ancient Turkic peoples.

However, before discussing sports contests culture, we need to consider the general theory of agonism. This is the theoretical aspect of the problem, and here we use the theoretical approaches and methodological basis of both foreign and Kazakh philosophy and culturology that study the theory of agonism.

The scientific and research part offered to the attention of experts is called "The origin, essence and forms of the Kazakh agon". It is the main topic, the subject of our study, but it is also the most initial, first part of the overall system of a large complex study called "The concept of agon in the world sports-competitive culture." The rest of the structural paragraphs - "Semiotics and the Specifics of Agon in the World Sports Culture" and "Typology of Worldwide National Battle Rites, Rituals and Military Sports Games" are not specifically considered in this article, although we can not ignore them.

The object of our study is the essence of agon, its genre and typological diversity, its origin.

Agon (battle, competition) is the source and root cause of human culture and civilization and the beginning of all dialectics. None of the historical, social and cultural phenomena could not have arisen, formed, evolved, approached its blossoming, decay and decline outside the internally embedded agon: battle, opposition, competition, polemic and controversy. Proceeding from this root cause, all thinkers, beginning with Heraclitus, deduce their theories about the origin, development and extinction of the world. This battle, competitiveness is 
the core and the beginning of the dialectics phenomena known to us. In Greek it is called an agon.

The main goal of the present study is to reveal the genesis of the world sport-competitive culture and the common and universal essence of the word agon, based the example of the origin of the Kazakh agonistic culture, a significant and independent part of which is a sports-competitive culture.

Such theoretical aspect requires the solution of several problems:

- $\quad$ to present the main foreign and domestic research approaches in the general theory of agonistic culture;

- $\quad$ to reveal national-specific patterns of genesis and essence of the Kazakh agon;

- $\quad$ to reveal the typology of Kazakh agonistic forms, their composition, structure, national specifics;

- $\quad$ explore the most common (universal) features of both national and world sports-competitive culture.

The practical importance of this research is based on the high need for the development and writing textbooks and teaching aids in the field of philosophy and methodology of teaching Kazakh sport culture, the implementation of the most valuable results in the educational and research process.

The novelty of this work should be recognized as follows:

- $\quad$ for the first time the concept of agon is considered on the national Kazakh material in comparison with the ancient Greek agon;

- for the first time the ideas of Kazakhstani theoreticians about the origin of agonistic forms of sports culture are laid in the basis of scientific and theoretical developments of agonism;

- $\quad$ for the first time based on the European theoretical and methodological base, various national agonistic forms became the subject of analysis.

The relevance of research

1 The relevance of the study is caused by two important reasons:

a) a serious lack of the necessary conceptual and theoretical data in the area of sports culture, the newest methods of identifying and interpreting the essence and origin of sports agonistics;

b) a general underestimation of the archaic agonistic forms of both sports and non-sports culture: the ancient agon manifests itself most specifically initially holistically;

2 In this sense, Kazakh cultural genesis, taking into account its nationally specific forms and conditions of formation, is a valuable source for understanding the world agon and exploring the general laws of the essence and origin of the world sports and competitive culture. This is the great merit of Kazakh researchers.

3 Kazakhstan gained an independent status. It has the right to popularize and promote its best examples of tangible and intangible cultural heritage, an independent part of which is the ancient Kazakh nomadic sportscompetitive culture;

4 The topic of agon finds particular relevance in the modern world, where there is a strong, open confrontation of religious, social, ideological, and other political forces.

Proceeding from the basic unifying idea of Pierre Coubertin: "Oh, sport! You are the whole world! ", We are developing the most relevant context of sports culture, namely: a) the universal value and general laws of the development of cultures and civilizations; b) humanistic context: the person is in the center of culture and he is the main object of research. Such understanding of the humanistic essence of the world and national culture should become the main source of science: knowing yourself as a national phenomenon in universal human existence and "recognizing yourself as the part of the world in the national context".Thus, the entire humanistic idea of research is oriented toward the path of unity and not confrontation. True opposition and rivalry, agon, can and should be realized only in a sporting format.

\section{Literature Review}

Agon as a concept of culture involves the study of a large body of sourcesF.A. BrockhausandI.A. Efron(1), DrachG.V(2),I.T. Frolova(3), Theatrical Encyclopedia(4),Scheglov G.V(5),Soviet Encyclopedia(6). Sometimes dictionaries allow inaccuracies and even the identification of the concept of agon with dialectics, and yet the main characteristic of agonism is "battle".

There are various agonistic forms: sports, art, (poetic and musical), etc. The study of the general theory of agon traditionally goes back to antiquity, to the Greek agonas, which are the four main ones: the Olympic Games in

776 year, the Pythian Games in 586 year, the Isthmian Games in 582 and the Nemean Games in 573 years. However, the agon finds its deep archaic origin in all ancient folklore, early literary and medieval monuments of epic culture: "The Epic of Gilgamesh" (the struggle of Gilgamesh with Enkidu), "The Song of the Nibelungs" (Brynhilda's struggle with Siegfried and the groom), Homer's "Iliad" (A match between Odysseus and the grooms).

Agonistic collisions are clearly manifested in the epics about the Russian heroes, in the Kazakh heroic and lyric-epic tales: "Koblandybatyr", "Alpamys", "Kyz-Zhybek", "KozyKorpesh and Bayan Sulu", in the archaic heroic tales of the Turkic-Mongolian peoples and in the oral poetry of akyns and zhyraus. For analysis, we took the ancient Turkic agon, imprinted in the archaic Kazakh fairy tale "Animal Dispute." This intertribal agon embodied the cosmic struggle of two opposing forces $(7,33 ; 8,537 ; 9,114)$

In the analysis of this agon, we used data on Turkic folklore, ethnography, and also an article of the 
Academic edition "Myths of the World Nations ". We reviewed the main foreign and Kazakh studies on the general problems of culturogenesis, (10, 114; eleven; 12).

This made it possible to clarify the genesis and essence of the adversarial culture and, in particular, sports agonism. The method of abstract review and review allowed us to understand the nature of agon and agonal forms more deeply.

The author of the thesis brings the systematization of theoretical concepts of different researchers, their scientific methodology is widely presented, agon and agonistic phenomena are interpreted, beginning with Aristotle and ending with the modern outstanding theorists of culture who have made up the classics of modern philosophy, aesthetics and culturology.

The researcher also brought into the system various agonistic forms of culture, depending on the genre and their functionally-intended purpose. In the thesis, the essence of agon as a game (J.Heasing), as a war, as aggression "(K.Lorenz), as a competition in friendship" (F.Junger) is analyzed in detail. The conceptual idea of K. Lorenz about aggression is of current interest, namely, that "aggressive behavior expresses the force of life affirmation through which humans preserves themself as a biological species", that "cultural mechanisms" are opposed to "destructive aggression", "protect people from destruction", "culture mediates aggression" has not lost its relevance.

Hence, we draw an important conclusion about the genesis of the forms of the modern world sports culture, from archaic thinking to international sports, to humanistic generalization.

Well-known pedagogue-researcher N.I. Ponomarev dedicated his monograph to the agonistic essence of sport and physical culture and their social significance. Despite the obvious ideological realities of Soviet times, his works have not lost their valuable scientific-methodological and general theoretical significance $(10,114)$.

The largest specialist in the field of antiquity, an outstanding scientist, author of a large number of works on ancient art and literature, Taho-Godi, brilliantly reveals the intellectual atmosphere of Greek life, the mythological and theatrical meaning of the life of the ancient Greeks, in his work called "Life as a stage game in the representation of the ancient Greeks". Her interpretation of life as a stage game allowed us to reveal typological parallels with the creative worldview of the ancient nomads of Central Asia and Southern Siberia, who lived in the same rich mythological past and preserved their initial foundations, archaic forms of language, thought and world-view $(11,264)$.

Theoretical approaches and productive judgments about the specifics and genesis of the Kazakh sports agonistic culture of domestic researchers: C. Akatayev, M. Balgymbayev, S. Bulekbayev, A. Burkitbayev, Y. Dymov, M. Kulkenov, U. Kuralov, P. Matushchak, S. Makhmetov, E. Sagyndykov, M. Tanikeyev, A. Toktabay, B. Totenayev(12-23) and others give the main significance to our research.

Thus, in the monograph called "National Oriental Martial Arts" S. Mahmetov and P. Matushchak disclose not only the importance of oriental martial arts, but explore their origins and national characteristics for the first time[19, 112].

The authors note the specific features inherent in the ancient Turkic physical culture, reveal the historical patterns of its differentiation and dialectic.

We consider the notes of some authors about the prevailing stereotype as fair enough, where under the national martial arts Japanese, Korean and Chinese martial arts are usually considered. However, "all the nations living on the territory of Central Asia and Kazakhstan" mastered the methods of martial arts. This is eloquently discribed in the "rock carvings and ancient manuscripts." Kazakh authors also constructively criticize Europeancentric concepts of European scholars. Thus, Professor S.B. Bulekbayev notes: "The role and place" of the Turks who played a significant role in antiquity, according to the "current classification of civilizations, they are not properly marked and not appreciated", and "they are dissolved in the notion of either nomadic (nomadic) civilization or Arab-Muslim". The object of his criticism was almost all the famous European scholars who are investigating the problem of civilization: O. Spengler, Danilevsky, A. Toynbee, S. Hantigton.

In general, the professor concerns the theory and features of cultural genesis, the importance of military sports of ancient and medieval Turkic peoples. The problem of genesis is devoted to the monograph "From the baiga to the Olympics" by M. Tanikeyev. For the first time in Soviet science, he turned to military rites and holidays, dating back to the era of the Turkic Kaganate (VI-VIII centuries), to the national history of physical culture, revealed its origins, presented a systematic classification of the oldest games of the Turkic peoples, such as kakakboran, kaltyraukkempir, yerte-kuzem, kesh-kuzem, kymyz-moryndyktan. The author considers them as a part of a special complex of military rites, customs and rituals.He applied for the first time the comparativetypological method, where he refers to the evaluation of ancient authors about the physical and moral characteristics of nomads $(8 ; 21)$. Such kind of qualities are undoubtedly connected with the military-nomadic way of life of the Turks, living in severe climatic and difficult military-political conditions. The scientist $\mathrm{S}$. Bulekbayev devoted separate chapters of his monograph called "The Turkic contribution to the world civilization" to the military art of the Turks $(13,316)$.It is also quite natural that authors often pay attention to the genesis and specificity of equestrian sports agonism because we are dealing with the so-called horse-nomadic civilization.

After distinguishing such important features for Kazakh agonistics as its general transitivity, syncretic character, etc., we compared it with the rapidly developing European civilization. 
Already in Aristotle's "Politics" we see the differentiation of the genres of art, a detailed classification of the controversial forms (agones). Such detailed Aristote's theory of imitation (mimesis) fully reflects the developed life of the Greek polis in its culturally specific diversity. The essential difference between the agonism of the settled Greeks (especially at the time of their prosperity) from the nomadic Turks remains important for us. Hence, the purpose of art is revealed: the ancient scientist highlights competitions in the general system of training and education of citizens of the state [24].

Noting the syncretic nature of the historical and cultural development of nomadic Turks and revealing the reasons of their slow development, some researchers attributed it due to the relative stability of the "patriarchaltribal superstructure".

Being agree with S. Akatayev's analysis in general, we do not quite agree with his characterization of the nomadic way of life as sustainable. Proceeding from the law of inevitable socio-historical development, such nomadic phenomenon is more accurately designated as the principle of universal transitivity.

This universal transitivity manifests itself in all areas of the material and spiritual life of nomads. By virtue of the principle of universal transitivity, we have the right to speak not only about the stability of the cultural tradition of nomads, but also of the historical continuity of their original traditions (foundations). The author rightly concludes that "the genetic chain of connections is not torn, and has its logical continuation in the life of Kazakhs and exists in our days". Agonistic art of akyns, its close connection with ancient ritual, initial, grounds, with funeral rites and a memorial tradition, dating back to mythology are remained until the twentieth century. Therefore, it is so important to proceed from syncretism (the undivided and unified music, word and action), the initial grounds of agonism [25], structure and semantics [26], where under the initial bases we have a myth, an archaic epic, rites and rituals associated with mythological representations.

These two main features, general transitivity and initial bases were preserved only among the nomads due to their slow socio-economic development. Under the initial bases, we actually have a myth, an archaic epos, rites and rituals connected with myth and mythological ideas.

In order to not to fall into ethnocentrism, we quote the views of prominent philosophers, M. Heidegger and F. Nietzsche about the crisis of European culture "in scant times".Both philosophers while discussing contemporary art, note that "culture has lost its roots" [27, 100; 28, 100].

While comparing the ancient lyrics with the modern European, F. Nietzsche describes it as a "deity without a head". In the final paragraph, both philosophers come to the value of syncretism and to the inevitable connection of the arts with "myth and music".

Here we proceed from two essential features that constitute the initial foundations of all archaic culture: 1. ancient musical origin; 2. the presence of the very tribal myth itself in the form of veneration of ancestral spirits (aruahs), or the deities of Tengri. Combat and musical-poetic agonistic art ere just dedicated to these spirits and this deity, as well as the gods of ancient Greece. The value of the military-sports agon of the Turkic peoples was maximally revealed by the remarkable Kazakh researcher E.D. Tursunov in his monograph called "Types of carriers of the Kazakh oral and poetic traditions" .

In his monographs dedicated to Kazakh folklore, the author traced the genesis of folkloric phenomena, genre forms, the formation, the specifics of the types of carriers of the oral-poetic tradition, the social functions of the genre, and the connection of the genre with the status of each individual singer.

He applied the method of complex-concentric study of folk-epic phenomena for the first time in folkloristics. The essence of this method is that there is one problem in the center of the research and all other problems are solved in it, creating a single conceptual sphere. This strongly distinguishes the method of E.D. Tursunov from the linear, European understanding of the method, since in the complex it allows us to see the syncretic phenomenon as an integral and as developing from the inside at the same time $(29,322)$.

In some monographs of this scientist there are examples of both the military-sports agon, as musical agonistic genres, as verbal contests like aitys, and dramatic ones, namely, the ritual-combat and military-theatrical art of the singers of the Slovians and Seres

It is such a methodological statement in the study of the nature and genesis of agonistics that seems to be the most correct for understanding the origin of any national sports culture and any kind of sport (and genre of art).

After the first Soviet Kazakh researchers: S. Makhmetov, M. Tanikeev, P. Matushchak, a large number of authors turned to the origins and theory of national sports. For example, the researcher M. Kulkenov gives a typological analysis and systematizes the sports-agonistic data, singling out such significant sports agonistic forms as: kokpar (fighting on horseback for a goat carcass), baige (horse races), kazakhkures (national Kazakh wrestling), zhambyatu (archery), zhorgazharysy (race of pacers), confrontation on horses (audaryspak), kyzқ uu (catch up the horsewoman), baige (horse races), mergendersaiysy (archery match), tengealu (pick up the money bag while riding a horse), togyzkumalak (a game of logic, like chess),shenber (circular wrestling), etc. (17, c.149).

\section{Research Methods}


1. Analysis and comparison of various dictionary articles on the topic of "agon". Complex selection and systematization of definitions of the concept. The aim of the method is to reveal the general features of agonism and to present a general typology of agonistic forms.

2. Comparative-typological method (comparative studies). In addition to the ancient traditions of agon, its deep archaic typical beginning is revealed in comparison of ancient folklore and early literary monuments of world culture.

3. Structural-analytical and explanatory-illustrative methods reveal the agonistic semantics of Turkic culture. The analysis of the initial foundations of this agon is based on the data of folklore and ethnography. "

4. Method of analytical review, a selection of the most relevant theories and methodologies in the field of the general theory of agon. The main method is the abstract review of the main foreign and Kazakhstani data.

5. Review and interpretation.

The method of reviewing and interpreting allows us to reveal the depth of the study of the problem. It includes the most popular authors of our time. For example, in this work, the fundamental work of A.V. Yarovoy and other researchers are referenced. This is extremely important for understanding the process of cultural genesis and the cultural essence of agonism.

6. Systematization of Russian and Kazakh sources.

The method of systematization makes it possible to identify basic, scientific-methodological and theoretical achievements in the field of the theory of sports agonism. An analysis of methodological and scientifictheoretical ideas related to the specifics and genesis of the Kazakh national competitive culture and methods of investigation was made.

7. Semiotic analysis of the Turkic agon.

Semiotic analysis of national (Turkic) agonistic forms is presented for the first time on the material of the ancient, eastern classical and European theoretical and methodological base; their communicative nature is revealed by generic attributes and binary, syncretism, universal transitivity, traditionality, connection with the archaic myth, epos, ancient rituals, customs and rituals.

8. Method from general to particular.

This method in the study seems to be the most correct in understanding the origin of the general laws of origin and development of national and world sports agonistics.

The main conclusion: although the laws of origin of agon and agonistic forms can be general, methodological approaches in their scientific investigation must take into account the features of national semantics and structure. It especially applies to the initial bases and the syncretic nature of the Kazakh agonistics.

9. Typological analysis.

Allows to bring the national data into the system and reveal the typological patterns, features of style and genre of agonistic forms.

\section{Problem description}

\section{General Theory of agon}

We have identified the concept of agon from the analysis of a large body of theoretical and encyclopedic sources. One of the dictionaries explains that "Agon" is actually a "fight or a contest" $(1,148)$ The researchers note that the competition for the ancient Greek games included music, singing, dancing and also dramatic works at the celebrations in honor of Dionysus $(1,148)$.

Some researchers include disputes here about contests of speakers: "In everyday life, the Greeks did everything to defend their opinion and achieve glory, furiously arguing and contrasting each thesis with an antithesis" $(2,12)$.

However, such extension can lead us to the boundaries of dialectics. This term in antiquity originally designated the dispute, "the ability to dispute through questions and answers" $(3,155)$. At the same time, other dictionaries, referring to aesthetics and the theory of ancient Attic comedy, explain the agon as "a verbal contest, a dispute between the main characters" $(4,67)$. Therefore, such a vivid researcher of agonism as A.V. Yarovoy, notes that the term "agon" has been repeatedly exposed and subjected to comprehension, especially if the researcher is interested in ancient culture and philosophy".At the same time, agon is the inevitable source of all dialectics. However, dialectics, both as a process and as an explanation (judgment) is connected with development, and agon seems to be a concrete struggle, direct rivalry. "Agon" is a struggle, competition (Greek), the striving for competition in almost all areas of public life.

The main role was played by sports, art, (poetic and musical) and equestrian competitions. Agon or agonism was the desire for sport successes, unlike athletics, professional sports $[6,13]$. As can be seen In this dictionary definition a common sign of agon is the struggle, the contest; The second sign is the desire to compete in all areas of public life; Thirdly, despite the visual classification of the presented agonistic forms, agon is presented as an aspiration for sport successes and highlights this sporting genre from the general body of a broad agonistic culture.

In any case, agon is only a struggle, only a competition. The object and the center of this agonistic culture is the person himself that creatively and intellectually use the forms of this diverse agonistic activity. Therefore, the genesis, essence and various forms of agon as a cultural phenomenon in general is considered by anthropology, 
the science of man.

The agonistic forms of culture are different and diverse:

- sports-competitive, for example: wrestling, chess;

- Scientific - polemic, discussion, opposition;

- Creative - contests and quizzes. They reflect the most diverse semantic areas of agonism: sports, poetic, musical, oratorical, etc.

An important essential feature of the agonistic style, its inalienable feature is its publicity. Agon is a public phenomenon: a contest presented to the public, a public demonstration of any confrontation.

The initial cultural and historical significance of agonism is physical struggle, public demonstration of one's physical superiority and dedication of adversarial art to gods and spirits.

The data on ethnography and mythology confirms that the agonas originated from the veneration of spirits and gods, As a victory they were first dedicated to the gods of the tribe, and then to the classical gods of wider national importance.It is well known from the history of the world sports and controversial culture that such contests and sport competitions in honor of the gods were held by the Greeks from prehistoric times, Also, in historical times every major Greek politician himself arranged his periodic contest games. Their origin, as well as that of the Turkic peoples, was originally associated with the characters of Greek mythology and dedicated to them. Therefore, the study of the theory and history of agon traditionally goes back to antiquity, to the Greek agonas, which are the four main ones: the Olympic Games in 776 year, the Pythian Games in 586 year, the Isthmian Games in 582 and the Nemean Games in 573years $(1,148)$.

Outside the ancient Greek traditions, the agon finds its deep archaic origin in all ancient folklore, early literary and medieval monuments of epic culture: "The Epic of Gilgamesh" (the struggle of Gilgamesh with Enkidu), "The Song of the Nibelungs" (Brünnhilde's struggle with Siegfried and the groom), The "Iliad" of Homer (a match between Odysseus and the grooms). Agonistic collisions also manifest themselves vividly in the epics about the Russian heroes, in the Kazakh heroic and lyric-epic tales: Koblandybatyr, Alpamys, KyzZhibek, Kozy-Korpesh and Bayan sulu, in the archaic heroic tales of the Turkic-Mongolian nations and in oral poetry of Kazakh akyns and zhyraus. This is a separate topic of world sports-competitive epic agonistics. All these agonistic types like verbal-musical and actually sports were associated with ancient pagan holidays, glorifying spirits, local gods and then gods. We see this not only in Ancient Greece, but also in Rome, India, China, Egypt and also among the Turkic nomadic peoples. For example, Kazakhs, like many Eastern nations, still celebrate the Nauryz or the New Year according to the Eastern calendar. New Year's agon is vividly captured in the Kazakh archaic tale "Animal Dispute". Here, under the images of the competing animals, there are twelve totems of different tribes. Both the number and names of the animals correspond to the number and names of the months of the eastern calendar. Their dispute, rivalry, competition reproduce the cosmic struggle of two initially opposing forces and have a mythological significance.

During the celebration of the New Day or New Year, dressed in all light clothes, the Turks gathered near rivers and lakes. They arranged spectacular and competitive events. Singers (akyns) of different tribes conducted musical-poetic competitions-aitys, and wrestlers had wrestling competitions. Thus they celebrated until the sunrise, the New Day and the New Year. All these spring verbal musical and sports (fighting games) competitions of the ancient Turks were dedicated to the god of spring and revival, the master of rivers and lakes, to whom they also sang hymns in the morning dawn $(7,537)$.

Türkic military customs and rituals were the personification of strength, dexterity, courage, and "the celebration of Nauruz (New Year) was inevitably accompanied by ritual combat". All these military sports games were combined with a special complex of rituals, customs, rituals $(8,33)$.

The Turks believed that during the night, from 21st to 22nd of March, there is a struggle of two opposite principles in space - light (white) and dark (black). The white beginning embodied good and abundance, and the dark one - hunger, misfortunes and failures of the next year. Semantically, this mythological struggle and the opposition of forces were represented by competing representatives of different clans and tribes. Therefore, the Turks had a great desire and even an acute need to help the bright spirits in this cosmic struggle. Therefore, just before sunrise, they not only performed abundant ritual sacrifices in honor of the god of rivers and lakes, but also arranged various musical and verbal and sports competitions in honor of nature spirits and ancestral spirits, trying to please them $[7,537]$.

The essence and genesis investigated by us form the key problems of philosophy, culture, aesthetics and the semiotics of the arts of both sports and nonsports like agon. Therefore, one of the objectives of our study was to review the main foreign and domestic (Kazakhstan) research approaches in the general theory of agonistic culture and sports agonistics in particular, and also in the origin of agonism.

The main method of our research here is the abstract review of the most relevant works.

For the first time in Russian studies, a detailed analysis of the essence of agon and agonal forms is presented in the dissertation research that we reviewed, "Agon and agonal culture" of A.V. Yarovoy.

The author provides detailed systematization of theoretical concepts of different researchers, their scientific methodology, analysis and interpretation of agon and agonistic phenomena, beginning with Aristotle and ending with modern outstanding culture theorists who have made up the classics of modern philosophy of culture, aesthetics and culturology. 
From his research we became aware of the first "concept of agonism and agonistics that was used by J. Burkhardt in lectures on the culture of Greece." He also reviews the approaches of A.I. Zaytsev to the installation of ancient Greek society that understands agon as a "superiority over others in achieving their life goals"; F. Kessidi, deriving agon from "the diversity of national characters as a result of biological heredity, established traditions and the choice of value orientations and preferences, accumulated historical experience and upbringing"; G.V. Dracha that brought out the system of regulation of social relations in Homeric society from the "heroic code" implied that competition, the agon itself, where fame and honor are confirmed by personal achievements ". A.V. Yarovoy notes that the term agon has several meanings and gives a distinction between agon as a struggle and as a contest. Proceeding from the "differences of ancient Greek policies" and "the traditional opposition of Athens and Sparta," he explores the nuances between struggle and competition, relying mainly on the understanding of the agonist F.G. Junger. However, in our opinion, the interpretation of Agon by F. Junger is characterized by such a breadth of filling the term, down to "Agon as a competition in friendship" (F. Jünger), which blurs its conceptual and semantic boundaries.

The author's (K. Lorenz) analysis of the conceptual essence: "agon and war", "agon and aggression" deserves special attention.

We consider this position to be very productive when "aggressive behavior expresses the force of life affirmation through which human is preserved as a biological species," when "destructive aggression" is opposed by "cultural mechanisms" that "protect people from destruction" when "aggressive forms of behavior are channeled by cultural Mechanisms" and "culture mediates aggression."

Hence, we are particularly clear about the prospect of a linear development of the sports agon. The process of intellectual comprehension of the cultural significance and essence of the agonum starts from the deadly combat rite and forms of "biological survival" and reaches the humanistic agonistic forms of the modern world sports culture. From archaic, tribal thinking to the world agon. From the traditional, to the international sport. In the format of our article, we can not be distracted only by the method of abstracting, therefore, turning our attention to the breadth of the theoretical problem, to the disagreements connected with the multiplicity of the meaning of the term agon, in order to concretize our problem, we point out the most interesting works of A. Yarovoi.

This is the definition of J. Hayzinga.

"Agon ( $\alpha \gamma \omega v$ - agon, Greek wrestling, wrestling) is the main form of performance in an ancient society, whose whole life was imbued with the principle of competitiveness. The agonas were sporting, musical, poetic, dramatic ".

The following important signs of agonism are reflected in here:

First, as the main type of performance in an ancient society, the one that shapes this type of culture, acting as a national and socially significant phenomenon;

Secondly: as a type and form of public speaking. Outside the evaluative, external response from the public, the spectators, the society, outside the "witness" of victory in the eyes of this public, agon does not exist;

Thirdly, the scientist puts forward the principle of competitiveness as the main substantive principle. It is clear that without this important element the phenomenon, the agoncan not exist itself;

Fourthly, the researcher presented various agonistic forms of culture depending on the genre and functionallyintended purpose.

In the end, they put forward the understanding of agon as a struggle and competition. By this notion and these features, we will confine ourselves so far.

Let's return to the idea of K. Lorenz "about aggression" and consider it on the example of the Kazakh fighting game "zhekpe-zhek" (head to head).

In ancient times the Kazakhs had a fighting duel of horsemen with spears called "zhekpe-zhek". This deadly single combat of two batyrs (Heroes), each of which represented his own tribe, certainly ended in the death of one of the competitors. If the tribe of the victorious Naisager spearman won, then the whole tribe lost in the moral plan, which lost valuable combat quality, one combat unit, one nomad warrior. Hence, the whole tribe received the damage.In the process of a long agonistic practice, there was a need for such a "cultural mechanism", where a person, a person's life and a quality are preserved. There comes a time when a meaningful culture "opposes aggression" or in the words of K. Lorenz, "mediates aggression." How does this happen? An equally dangerous, but still not so deadly "cultural mechanism" called "aitys" emerges out of the bosom of a universal and single ancestral agonistic culture. Aitys is a verbal and musical competition of two representatives of different clans, an irreconcilable confrontation that completely replaces the deadly battle. Thus, the deadly form of agony was replaced by its vital cultural form. The main thing remained. It is the agonistic essence. However, it is not that a simple and effective form of substitution of one agon to another does not have "aggressive" consequences.

Here, it is important to take into account another thing: a sacred-magical, suggestive plan and a negative impact of the magic word on the enemy (harmfulness, perniciousness).

In the ancient mythological worldview of the nomad it had, perhaps, a more urgent meaning, possessed a greater "destroying" force than a real existent, materially tangible spear. The word of aitys man was a formidable, invisible, full of destructive negative energy (curse and spell) spiritual weapons. However, in reality, "an aggressive form of behavior is regulated by a cultural mechanism." 
Here we need the process of cultural genesis, the process of intellectual comprehension of the cultural essence of agon, the process of transition from a deadly fighting rite, from the forms of "biological survival" to human and humanistic agonistic forms of the modern world sporting culture, as the humanist and poet, the great Pierre Coubertin dreamed. However, like any national traditional culture, Kazakh has its own unique national essence, its original forms and attributes. These essence, forms and attributes are caused by historical, climatic and geo landscape factors. The main thing is a remaining of person, which is the source of agon. The struggle remains as the basis of agonism. Agonistic forms, signs and structure remains. The most important feature at the heart of this structure is binary opposition.

All this set of properties, attributes and structure creates an essence of a modern world sportscompetitive culture.

The works of major researchers who created the foundations of scientific sports agonistics (the science of contests and struggle), such as N.I. Ponomarev and A.A. Tahoe-Godi. Thus, the famous Soviet teacher and researcher N.I. Ponomarev in his monograph "The Emergence and Initial Development of Physical Education", for the first time concerns the agonistic essence of sport and physical culture, their emergence, essence, social pedagogical and aesthetic significance and their functional purpose. His work "The emergence and initial development of physical education", has not lost important scientific, methodological and theoretical significance to this day despite the ideological realities of Soviet times $(10,114)$.

The most outstanding Soviet researcher of antique agonistic genres is the largest anthro-scientist A. A. Tahoe-Godi, the author of numerous articles, monographs and textbooks on the culture of the ancient Greeks. The scientist brilliantly reveals the mythological and theatrical-stage meaning of the folk life of the ancient Greeks in his widely known work "Life as a stage game in the representation of the ancient Greeks,". Her interpretation of life as a stage game in the representations of the ancient Greeks is very close to understanding the Kazakh nomadic worldview. It was typologically close to it, due to the fact that the nomads, unlike many peoples, preserved a rich mythological heritage, archaic forms of language, way of thinking and worldview, which are close to the ancient Greeks. This was repeatedly noted in modern scientific research. The Turkic nomads did not go far from the Greeks, or rather they were even older than Greeks, which makes many genres of ancient Greek musical and song poetry of these two peoples so close. Here, the typological parallels of the ancient Greeks with the creative worldview of the ancient nomads of Central Asia and Southern Siberia are created(11, 264). Several well-known Kazakhstani authors left us various theoretical approaches, analysis, comments, deep and productive judgments about the specifics and genesis of the Kazakh national sports agonistic culture: C. Akataev, M. Balgymbaev S. Bulekbaev, A. Burkitbaev, Y. Dymov, M. Kulkenov, U. Kuralov, P. Matushchak, S. Makhmetov, E. Sagyndykov, M. Tanikeyev, A. Toktabay, B. Tottentaev(12-23).

The works of these researchers are of primary importance in understanding the essence and genesis of the Kazakh agonist and agonistic culture, although none of them specifically set the goal to investigate the national essence of Kazakh sports agonism. Yet, they did not ignore the emergence, national characteristics and agonistic forms of Kazakh sports culture in their numerous articles and scientific monographs on the Kazakh sport.

Thus, in one of the studies, the authors, noting that "national oriental martial arts" is a "treasure of human culture," raise the question of their genesis: "each nation at certain stages of its historical development inevitably created the techniques of hand-to-hand combat, struggle and disarming, which were vital in wars, civil strifes and occasional battles "[19, 3]. They disclose specific features for the first time, their historical patterns, inherent in the ancient Kazakh physical culture, their differentiation and dialectics: "Syncretic nature was a part of physical culture too, which means that it was still merged with the productive activity of society. The appearance of such table games as "Togyz-kumalak" and "Mankala" speaks, apparently, about the process of differentiation "[8, 17].

It is a fair remark of this and other authors about the stereotype that under the national oriental agonistic martial arts, people usually consider Japanese, Korean and Chinese. However, "all peoples living in the territory of Central Asia and Kazakhstan mastered the methods of single combat" and "rock paintings and ancient manuscripts" speak about this eloquently "[19,4].

However, "when it comes to national martial arts, only Japanese are mentioned - jiu-jitsu, judo, ninjido, aikido, karate, sumo or related Chinese yu-shu, kung-fu, Korean taekwondo and Europeanized martial art like kickboxing." Due to "long-term advertising" Japanese combat systems were the most known to the general public.

The monograph "From Baiga to the Olympics" by M. Tanikeev is devoted to The problem of genesis. For the first time in Soviet science, he studied military rituals and festivals dating back to the era of the Turkic Kaganate (VI-VIII centuries), to the history of Kazakh physical culture, revealed its features, introduced a systemic classification of the oldest games of the Turkic peoples. The author considers them to be part of a special complex of military rites, customs and rituals [8, 33].

In his studies, he conducted a comparative-typological method for the first time. Thus, he refers to the evaluation by the ancient authors of the physical and moral characteristics of nomadic-massagets [21, 7]. In his example, "Greek authors write about the courage, fearlessness, physical qualities of the nomads of Central Asia and Kazakhstan", and that: "... they are good mounted and foot soldiers ..." [21,7] that they "were relatively tall 
with Highly developed musculature ... Superiority in physical strength, agility and courage, in the art of riding and archery, the ability of using weapons helped them to defeat their enemies [21, 7].

That is why the statements of the president of Republic of Kazakhstan, N.A. Nazarbayev, about that "... each of us was engaged in physical exercises, fed right, took care of the hygiene and sanitation measures ..." (24). All the qualities listed by him are undoubtedly connected with the peculiarities of the ancient severe militarynomadic way of life: "the life of a nomad was fraught with great difficulties. Moving from place to place, constant care of livestock and many other features of nomadic lifestyle made high demands on members of society. Running, fighting, throwing, shooting, riding and other physical exercises are used to prepare the younger generation for a nomadic way of life "[8, 31]. It is quite natural that most Kazakhstani authors pay attention to the genesis and specificity of equestrian sports agonism: "military art is the pride of a mounted warrior: an easy saddle on a horse, an irreproachable ability to stay in the saddle, the art of jiggeting. The warrior had to withhold on the horse so that no one could move him or throw him to the ground because this is what the opponents are trying to do in a duel "[14, 204].

The scientist dedicated individual chapters of his monograph to the military art of the Turks. He constructively criticizes the works and concepts of many European and Russian scientists. Noting the historical role and place of the Turks in the world civilization, he notices that in the "current classification of civilizations, the Turks are not marked properly and not appreciated", that "they dissolve in the notion of either a nomadic (nomadic) civilization or an Arab Muslim". He writes that "almost all the famous European scholars that study the problem of civilization, such as O. Spengler, N. Danilevsky, A. Toynbee, S. Hantigton and others, deny the right of Turks to own an independent civilization" $[14,15]$. Although the criticism of the theories of Eurocentrism and ethnocentrism is an important aspect of the issue of the role and place of the Turkic civilization, but it represents a separate topic of scientific research.

The heart of an agonistic culture (center, object) is always a human. Agonistic culture has both common (universal), the laws of origin inherent in the whole human community and national-specific features, semantics, style and structure.

For the first time, based on the data of the ancient and European theoretical and methodological base, our subject of analysis are national agonistic forms, phenomena and events.

Foreign researchers of world sports agonistics may have a quite reasonable question: why do we consider the essence and origins of the world sports agon through the culture unknown to us, to the majority of Europeans?

\section{Arguments:}

Firstly, we initially consider not so much of a sports agon, as agon as a whole, every struggle and every rivalry and competition; Secondly, in our principled attitudes, we proceed from the following extremely important circumstance, which with a detailed presentation of Kazakh culture, should not seem unexpected and reprehensible to modern researchers oriented to a purely European classical paradigm, beginning with Greek antiquity.

Let's pay attention of researchers to one important thing for the Kazakh agonist circumstance: the art of the ancient and medieval nomadic movement was of a syncretic nature. It did not differentiate as quickly as in Europe. Rapidly evolving, European art often came to a crisis, to a revival, to a classic, to the search of new forms and then to formalism and deconstructionism, which was not and could not be in the eastern classical cultures until modern times, where In the culture of the Kazakh nomadism until the middle of the twentieth century. Therefore, the Kazakh agon seems to us as original phenomenon of human culture.Afterpaying attention to such sign as syncretism, which is stable for the Kazakh agonist, many scientists compare this culture with a rapidly developing European civilization.

There is not only differentiation and classification in the writings of Aristotle, but also a detailed analysis of the controversial arts (agones). Aristotle's time is the heyday of the Greek polis, the time of development and differentiation of the genres of arts, their main forms: epic, lyric, tragedy, comedy, dithyramb, avettics and cypheristics.

Such a detailed Aristotle's theory of imitation (mimesis) quite naturally reflected the life of the Greek polis in its cultural-specific diversity at the highest peak of socio-historical development. The main issue here is the essential difference between the agonism of the settled Greeks (especially at the time of their heyday) from the nomadic Turks. Thus, the ancient scientist pays special attention to competitions in the general system of training and education of citizens of the state [25, 285-287].

Take his "Politics".

In addition to a detailed analysis of the state and public life of the ancient Greeks, the philosopher discusses professional training in music, and it is about such training that prepares to speak in the competition $[25,287]$ Concerning the teaching of music, Aristotle presented the following controversial forms (agones): hymnal, Dionysic, musical and professional. The philosopher speaks of the upbringing and education of young men as citizens, emphasizing "that music classes should not interfere with the subsequent activities of a person and should not physically turn him into an artisan, render him unfit for military and civil duties. This can be achieved by teaching music, if young people do not exercise with strenuous efforts to take part in professional competitions "[25, 285]. 
Not in the nomad camp.

Social and historical conditions are different here. Agon is different too. Therefore, let us consider the features of the Kazakh agon.

The syncretic, undivided nature of the nomadic Kazakh agonistics is due to the fact that "the production basis of nomadic societies over which the patriarchal-tribal superstructure is mainly based on extensive cattle breeding, and therefore shows relative stability in its development" [12,13]. While supporting this point of view, we also disagree with the term "sustainability" which is applied to the nomadic way of life. Proceeding from the law of inevitable socio-historical development, we characterize this feature as universal transitivity. We are talking about a permanent process, and it is about the incompleteness of the process, which does not require its completeness and does not aspire to it, but constantly developing and changing without any more or less distinct borders. This sign of universal transitivity is the legacy of antiquity, which also manifested in all areas of the material and spiritual life of nomads, in all its diverse elements.

For example, the ancient syncretism (the original unity of music, words and actions) is a striking feature of the agonistic cultures of nomads. Such a statement of ours has an endless interest for science from the point of view of genetic history or the initial basis of all agonism. By virtue of the principle of universal transitivity, we have the right to speak not only about the stability of the cultural tradition of nomads, but also about the cultural and historical continuity of their original traditions (foundations). The author writes: "The ancient tribes on the territory of Kazakhstan were formed on the basis of certain ethno-cultural substrates, and their achievements in material and spiritual culture were the basis for the formation of the late Kazakh culture. This genetic thread of connections is torn nowhere and has its logical continuation in the life of Kazakhs and exists in our days "[12, 7].

We clearly see that, up to the 20th century, the agonistic art of akyns remained in traditional Kazakh culture, its close connection with ancient ritual, initial, funeral rites and a memorial tradition, ascending to mythology, to the cult of ancestors. Under these initial grounds, we actually have a myth, an archaic epos, as well as rituals that are closely related to religious and mythological ideas. We first mentioned the initial foundations of Kazakh agonistics, touching on the problems of translating oral poetry [26, 268] and the structure and semantics of the Turkic epic verse [27, 160].

The two main signs, which are universal transitivity and initial foundations have been preserved among the peoples of Central Asia and Southern Siberia due to their slow socio-economic development.

It should not seem to foreign researchers that our ideas are based on ethnocentrism. The Kazakh agon is needed only as an example of a preserved archaic culture, as an object of research with its initial foundations. In the archaic period, all peoples had their initial foundations, but because of rapid historical development they lost them. This is also the opinion of outstanding philosophers: F. Nietzsche about his contemporary poetic art and M. Heidegger about the crisis of European culture "in critical times".

Let us cite their assessment about the crisis of European culture of the twentieth century. Thus, M. Heidegger writes: "The world era, which has no foundation is suspended from the abyss. There is still a turning point to imagine that in the scanty days, we can only assume that the world will touch the ground again, but it means that a change in the course is possible solely starting from the abyss "[28, 76].

It is quite clear that the modern philosopher talks about the absence of initial grounds, about the scanty times of contemporary European culture. Characteristic of the era as a scanty time, he took from the article of F. Herderlin"Is there a need for poets in critical times?". However, even before the famous philosopher of the scanty times of European art, there was such a brilliant thinker as F. Nietzsche.

Arguing about the crisis of the modern arts of Europe, the philosopher Friedrich Nietzsche noted: "Let us now attach to this the most important phenomenon of all ancient lyric poetry. Everywhere the connection and even the identity of the lyric with the musician is recognized as quite natural, compared to which our newest lyric poetry appears as a statue of a deity without a head ... The lyrics from the abyss of being sounds like this, his "subjectivity" in the sense of the newest aesthetics is only imagination "[29, 73-74]. In this case, the philosopher is mentioning syncretism ("the connection and even the identity of the lyric with the musician", that is, the primordiality of the arts). In the very same concept, F. Nietzsche directly derives the "myth from music". Thus, long before M. Heidegger, by comparing European culture with the ancient one, the philosopher Nietzsche writes about the loss of the initial grounds in his modern lyrics.Let's add to the fact that he characterizes ancient lyric poetry as a "deity with a head". It reveals its higher mythological essence, its organic connection with music and myth. He understands this connection more widely, for both tragedy, as a genre of drama art, and not so much from music, as from the spirit of music - the true source of myth flows out from him. In the same way, in the analysis of ancient agonistic Kazakh forms, we mean their pure and original syncretic state. The metaphorical combination "deity with a head" is quite applicable to these nomadic forms. Here, we proceed from two essential features that constitute the initial foundations of any archaic culture:

1. Ancientmusicalorigin;

2. The presence of the tribal myth itself in the form of veneration of the ancestral spirits (aruahs), or the deities of Tengri.

Military and musical and poetic agonistic art of the Turks were just dedicated to the these spirits and this deity, the same as with the gods of ancient Greece. Later, after development, the agonistic art of the Kazakh nomads was not perceived as an abstract game, as a separately and independently emerged and independently functioning phenomenon. For example, martial arts and the national, military-sporting tribal games that came 
out from them, were an organic part of the nomad's combat life. They were the main etiological content of ancient holidays, as well as musical and verbal agonas, rituals and military tribal rites-initiations.

The value of the military-sports agronomy of the Turkic peoples was firstly revealed in his monograph called "Types of carriers of the Kazakh oral-poetic tradition" by the remarkable Kazakh scientist E.D. Tursunov $[30,322]$. In his monographs dedicated to Kazakh folklore, the author traced the genesis of folkloric phenomena, genre forms, the formation, the specifics of the types of carriers (singers) of the oral-poetic tradition, the social functions of the genre and the connection of the genre with the status of each individual singer.

For the first time in folkloristics he applied the method of complex-concentric research of the genesis of folklore-epic phenomena, when the phenomenon is at the center of the scientific problem, and all other problems and all other phenomena are solved through the central one, creating a single communicative space called the semiosphere. This strongly distinguishes the method of E.D. Tursunov from the usual to us, linear, European. The method allows us to see the syncretic phenomenon in a complex as an integral, as it is developing from the inside, which corresponds to the most syncretic nature of the Kazakh agonistic culture. Examples of both the military sport agon as musical agonistic genres, both verbal contests, aitys and dramatic ones, namely, ritualcombat and military-theatrical art of the singersSals and Seres are given in the dissertations and in separate monographs of the scientist, [30, 222-227] All Kazakh researchers, due to the undeveloped theory of agonism, the specifics and richness of traditional competitive national forms, increasingly turn to the genesis of the Kazakh agon.

Let us consider this phenomenon. $\quad$ Of course, the unifying (syncretic) principle of all primitive arts from different peoples was the totem, an ancient tribal cult in the form of an animal (leopard, lion, leopard, etc.). This patron of the tribe was the source of combat and hunting magic, of all combat and hunting rituals and archaic heroic tribal myth and epic. The totemic tribal cult was the only and powerful remedy in the struggle of man with the elemental forces of nature. Through its comprehension, the agon took a shape of a binary system: "native-stranger". This ancient agon subsequently became a source not only for myth and epos, but also for all future epic, musical, dramatic genres and martial arts. Therefore, we call all of these forms as agonistic. Since all these military sports, musical, poetic and dramatic genre forms originally had a cult, religious-mythological, sacral-ritual significance, we came to an understanding of the original source of the ancient agon, all its agonistic genres, both sporting and nonsporting. Therefore, in order to identify the most general laws of the development of sports-competitive culture, its common origins and essence, we will consider in more detail the features of the Kazakh agon and its various agonistic forms.

\section{Features of the Kazakh agon.}

The common thing for all the world controversial arts is that all the ancient original agonistic forms were the core of the myth and served as a sacred background for the rite of consecration in honor of some deity, and later in honor of the spirit of the deceased hero. The military-nomadic way of life of the ancient and medieval nomadKazakh was literally imbued with a living and universal musical-poetic and combat heroic atmosphere. Art, by virtue of stability and general transitivity, did not aspire to a clear classical differentiation, as we have shown above, but had a utilitarian: military-applied, educational, traditional, purely practical purpose. This is the first feature of the agonistic Kazakh culture.

The Kazakhs, as well as in Ancient Greece, had a basic principle of competitiveness, which was the engine of the skills and competition of participants. As in ancient Greece, he manifested himself in all areas of social life and in all art genres, bringing everything that seems disjointed, elements of the social life of nomadism into a single system, into a single organization according to the principle of strength, skill or talent.

We include all the national types (genres) of physical opposition (predominantly equestrian), competitiveness in military sports and ritual-combat activities to the sports agonies of the ancient Turks; To musical - musical agonistic genre forms: the performance of kuis, musical agonistic plays (for example, the famous kui about the confrontation of the death of shaman Korkyt); To poetic - all kinds and genres of aityses (public competitions of singers-akyns); To the dramatic - the ritual-combat and military-theatrical art of the singers of sals and seres. The syncretism and peculiarity of the oral existence of agonistic genres (aitys), and the forms of their performance and functioning, and the most basic - its close connection with the ancient ritual, initial, with funeral rites and a memorial tradition.

This methodological statement in the study of the nature and genesis of agonismseems to us as the most correct for understanding the origin of any national sports culture and any kind of sport (and genre of art). It is enough to say that in our age of computer and innovative technologies, regional Kazakh musical epic, composer and performing schools-live museums in the open air still exist. These are natural laboratories for studying the origins and essence of any agonistic forms.

We defined the initial bases as the main source of agon: combat rites and rituals, myth and epos. These military-combat, funeral rites and various initiatory rituals in primitive archaic art were not separated from their basis, which are the clan cult, myth and archaic epos. They were the source of priestly military magic, the sacred core of the universal mythological knowledge of the struggle of the original elements, the struggle and unity of opposites. From the very beginning, they already had agonistic nature. They were also the product and the further source of all subsequent agonistic processes in the epos, lyric, drama and sport. It is first. Then we found the following feature. 
Both ancient, Turkic archaic, and medieval, Kazakh, agonistic cultures were based on sports-combat and musical-verbal principles. The agonistics was not only "a military-mobilizing remedy that preserves the tribe" (according to K. Lorenz), but also an intellectual engine of cognition and mastery of objective reality. It enriched cultural experience from tribe to tribe, from tribe to nation and state, establishing itself as a national phenomenon in the universal human system of cultures and civilizations, in the universal order of classic national values.

The third important feature of Kazakh agonistics is its signs, such as the stability or transitivity of forms, processes and phenomena.

This tribal feature of the nomadic Kazakh culture reveals itself not only in agonistic forms, but also at all its levels: the specific nature of Kazakh statehood as an image of the ancient and slowly changing forms of the horse-nomadic empire; The archaic basis of the Kazakh language, philosophy and literature as products of the oral phenomenon, oriental semantics and the structure of the Kazakh epic verse, etc.

In one word, we are dealing with a deep and primordial traditional culture that is unbroken and unlimited. Blacksmith, and jewelry, and oral-poetic, and horse-military art are correlated with centuries-old tradition, folk habit, with a measured way of life, with archaic folklore.

The same goes for the musical agon, which preserved its sacred space, its ritual-ceremonial functions, and, consequently, its unique ethical and aesthetic essence, which sharply distinguishes it from the classical sedentary cultures of the East and the West.

The fourth feature in understanding the essence and origin of sports agonistics is that among all types of archaic arts, martial and musical arts arose earlier than others.

Martial arts are the forerunners of world sports.

The emergence of military rites and rituals was directly related to the historical survival of the tribe in the face of sharp confrontation, brutal competition with other tribes for water and food. Every human race needed, strong, hardy members of the collective for its survival, moreover, they were suppose to be enterprising and quick minds. From this historical need for survival and self-affirmation in a hostile existence, there was a rise of a great variety of national martial games and military tribal rituals, the main purpose of which was to prepare the male population for the protection of the clan, the tribe, the food and the protection of the territory. As we have shown above, the national, Turkic, Slavic, Scandinavian, Pacific combat games and military tribal rituals are based on their national mythology, their specific tribal military magic, the original cultural complex of physical and moral training of the warrior boys with the overcoming of difficult physical tasks, the upbringing of the spirit and willpower (initiation), etc.

The historical process of isolating and further forming purely martial national arts and folk sports from the sphere of tribal (ritual and mythological) and traditional everyday life in the sphere of modern sports games has a very long history of its formation and comprehension.

The fifth feature is that among the all agonistic arts the verbal agon is the latest formulated type of agon. Subsequently, it came out most resolutely from this series, having played its historical role in the formation of myth and epos and their further flourishing. It was the word, in the process of its historical development and ever increasing role in the tribal rite that was the main reason for their destruction: demythologization and desacralization of the initial foundations: myth, battle rite and ritual, preparing the fundament for the national classical epos, folklore narrative genres, religion and the arts. Due to socio-historical changes from antiquity to modern times, this original agon regularly recreates the same ancient archetypal model in the various new historical forms, or the system of binary opposition: "local-stranger". This model is based on the same principle of the archaic confrontation between the "fair" and "better humanity" in relation to the opponent. All this myth-ritual semantics can be easily read in both simple children's competitive games and in a wide format of world championships, at the Asian or Olympic games, etc.

\section{Form of Kazakh agonistics}

Let's now consider the agonistic forms of the Kazakh sports culture. After the first Soviet Kazakh researchers: S. Makhmetov, M. Tanikeev, P. Matushchak, a large number of authors turned to the origins and theory of national sports.

Thus, by systematizing sports data, the researcher M. Tanikeev emphasized such agonistic form, as alaman-bayga, burkitsalu - hunting with eagles, Zhayau-zharys - running race, kokpar (fight on horseback for a goat carcass) bayge (horse racing), Kazakh kures (Kazakh national wrestling), Zhambaatu (archery), zhorgazharysy (upmanship Pacers), the confrontation on horseback (audaryspak)) kyzkuu (catch the girl rider), bayge (horse racing ) mergendersaiysy (archery competition), tayak-zhugirtu - javelin competition , tengealu (to raise money bag that lies on the ground, while riding a horse), togyzkumalak (logic game, like chess), tuyezharys - race on camels, shenber (circular wrestling), etc. [17, 5]. A completely independent group is made up for children's sports agonies and even some wedding ones, for example, zhar-zhar ("friend-spouse"), which the scientist M.O. Auezov referred to the variety of aitys.

All these agonistic forms of creativity retain their original archaic mythological binary symbols and semiotics in their structure. Some of them have come a long way from folk, purely traditional, to modern world (for example, from Kazakh kures to sambo).

Equestrian competitions are considered as a priority form of competition of the Kazakh sports culture. This is due to the long military-nomadic way of life. From the reports of ancient authors, we are well aware that Saks tribes, also organized various equestrian competitions. Many ancient agonistic types, also have reached us and 
became modern: the tightening of ropes (arkantartys), togyz-kumalak (intellectual game like chess), mergenderSaiysy (shooting match), Kazakh kures (Kazakh wrestling) and many others. With all the big variety, Kazakh sports agonistic forms were a single, integral part of the military-nomadic way of life.

Thus, the entire world sports-competitive culture also has various national agonistic forms. These forms of sports art appear in a rich typological variety. They are characterized by the following features: binary, syncretic primacy, traditionality, its connection with the archaic myth and epos, connection with ancient combat rites, customs and rituals and modern folk agonistic games. Although the laws of origin of agon and agonistic forms can be common,the approaches in the scientific study of them as national phenomena, must take into account the features of national semantics, genesis and structure.

\section{Conclusion}

1. Like any national agonistic culture, the Kazakh has its inherent unique essence and its original forms and attributes. These essence, forms and attributes are caused by historical, climatic and geolanscape causes. The main the source of agon is human. The struggle remains as the basis of agonism. Agonistic forms, signs and structure remains. The heart of this structure is a binary opposition and counteraction. The totality of these properties, attributes together with the structure, constitutes the essence of a modern adversarial culture.

2. The two main features, universal transitivity and initial foundations were preserved only among the nomadic peoples of Central Asia and South Siberia due to their slow socioeconomic development. Until the 20th century traditional Kazakh culture agonistic art of akyns was retained, its close connection with ancient ceremonial ritual, initial, foundations: funeral rituals and memorial traditions, ascending to mythology, to the cult of ancestors. Under these initial grounds, we actually have a myth, an archaic epos, as well as rituals and customs, which are closely related to religious and mythological ideas.

3. The art of the ancient and medieval nomadic movement was of a syncretic nature and did not differentiate as quickly as in Europe. Rapidly evolving, European art often came to a crisis, to a revival, to a classic, to the search for new forms and then to formalism and deconstructionism, which was not and could not be in the eastern classical cultures until modern times, where in the culture of the Kazakh nomadism until the middle of the twentieth century. Therefore, the traditional Kazakh agon is a pure, primordial and original phenomenon of human culture and is of great interest for science.

4. Martial arts and national, military-sporting tribal games that come out from them were an organic part of the military-nomadic way of life of Kazakhs. They, as well as musical and verbal agonas, constituted from the very beginning the basic etiological content of ancient holidays, rituals and military tribal ritesinitiations, had an initially cult, religious-mythological meaning in archaic folklore. They were part of the rite of consecration in honor of some deity, and later - in honor of the spirit of the deceased hero, which means that they were the language and demonstration of the myth;

5. The totemic tribal cult was the only and powerful meas in the struggle of man with the elemental forces of nature. Through its comprehension, the agon took a shape of binary system called"local-stranger". This ancient agon subsequently became a source not only for myth and epos, but also for all future epic, musical, dramatic genres and martial arts. Therefore, we call all of these forms as agonistic.

6. Ancient Turkic archaic and medieval Kazakh agonistic cultures were based on sports-combat and musical-verbal principles. They were not only "a military-mobilizing means of preserving the tribe" (K. Lorenz), but also an intellectual engine for learning and mastering objective reality. Enriching their experience from one tribe to another, from the tribe to the people and the state, the Kazakh agonistics has established itself as a national phenomenon in the universal human civilization system, in the universal order of classical national values.

7. Due to socio-historical changes the original agon regularly recreates the same ancient archetypal model in the various new historical forms, from antiquity to modern times, or the system of binary opposition: "LocalStranger" based on the same principle of the archaic confrontation of the "Fair", "Better humanity" in relation to the opponent. This myth-ritual semantics is easy to read from both simple children's competitive games and the format of world championships, at the Asian or Olympic games, etc.

8. World and national agonistic forms, genres and art appear in a rich typological diversity. They are characterized by the following features: binary, syncretic primacy, traditionality, its connection with the archaic myth and epic, connection with ancient battle rites, customs and rituals. Therefore, although the laws of the origin of agon and agonistic forms can be common, approaches in the scientific study of them as national phenomena must take into account the features of national semantics and structure.

9. The most complete and valuable value of agonism as an image of worthy struggle and rivalry, as it was understood by both ancient nomads and ancient Greeks presented in here.

\section{References}

A. Brockhaus F.A. and Efron I.A. Encyclopedic Dictionary. Reprintedreproduction of the edition // T. I. "Terra-Terra", 1990 p.480

B. Drach G.V. Agon. Dictionary Reference Book. Rostov: Phoenix Publishing House In the book: "Man and 
Society. Culturology "., 1996. p.544

C. Ed. FrolovaI.T. Philosophical Dictionary /. - 7 th ed., and add. - M .: Republic, 2001. p.719

D. Agon. Theatrical Encyclopedia in V vol., Vol.I. // M. 1961 -p.1214

E. Scheglov G.V. Archer V. Dictionary of Antiquity. / Moscow, 2006 -p.415

F. "Mythology of Turkic-speaking peoples" In the book: Myths of the World Peoples, vol. 2. // Soviet Encyclopedia, 1980. -p.720

G. Zhanabaev K. Nauryz is the happy frontier of our ancestors https://www.caravan.kz/gazeta/kajjrat-zhanabaev-nauryz-schastlivyjj-rubezh-nashikh-predkov-83658/

H. Tanikeev M.T. From Baiga to the Olympics. / Alma-Ata: Kazakhstan, 1983. - p.208

I. Ponomarev N.I. The Emergence and Initial Development of Physical Education. M., 1970. -p.114

J. Takho-Godi, Losev A.Greek Culture in Myths, Symbols and Terms// www.twirpx.com/file/645963/

K. Akataev S. About the specificity of the Nomadic Culture / In: Nomad - Aesthetics. (The cognition of the world by traditional Kazakh art). Almaty: Gylym, 1993. -p.264

L. BalgymbayevM. «The types of kazakh national sport games» Almaty, 1985, p.8613Bulekbaev S.B. Turkic Contribution to the World Civilization. // Almaty, LLP "Bavissystems", 2016. -p.316

M. BurkitbayevA.«The Types of National Sport Games and its impact on Upbringing» (Almaty, 1998). pp.16-21

N. Dymov, Ian. Will of Batyr. - Astana: Yer-Daulet, 2007. -p.388 : a photo. - (Sport sanlaktary).

O. Kulkenov M. World and National Sport Games. Encyclopedy. Almaty, «Mereke publishing». - 2014. p. 272

P. Kuralov U.N. Prototurks and the origin of the ancient Olympic Games / - Almaty, 2014 -p.152

Q. Matuschak P.F., Mahmetov S.G. National Oriental Martial Arts. - Almaty: Kazakhstan, TG "Didar", 1991. -p.112

R. Sagyndykov Y. «Kazakh National Games» Almaty, 1994, pp.58 - 61

S. Tanikeev M. Kazakh National Sports and Games. Alma-Ata:Kazgosiz -1957 -62p.

T. Toktabay A. The History of Kazakh Horse.Almaty, 2010, p. 496 «Kazakh National Games» Almaty, 1994, p.27

U. Message from the Head of State N.A. Nazarbayev to the people of Kazakhstan

V. "Kazakhstan Way -2050: One goal, common interests, commonfuture "// Kazakhstanskaya Pravda, January 18, 2014.

W. Aristotle. Politics. / Trans. S.A. Zhebelev and M.L. Gasparov. - Moscow: Publishing House AST, 2002 393 pages (Philosophy).

X. Zhanabayev K. The Poetic System of the Zhyrau works of the XV-XVIII centuries: initial foundations of artistic translation. А .: Қазақ университеті, $2014-$ p.268

Y. Zhanabayev K. Turkic Myth in the Epos, Rite and Ritual. А .: Қазақ университеті, 2016 -p.160

Z. Pilyavsky N. Try the Night: Heidegger and the Words (experience of reading). // Journal: Tamyr №1 (41), $2015-$ p.100

AA. Nietzsche F. The Birth of Tragedy from the Spirit of Music. Philosophy. Works: In 2 vol. M.: Mysl, 1990. T.1.p.231

BB. TursunovE.D. Origin of Carriers of Kazakh Folklore. - Almaty: Dike Press, 2004. p.322 